\title{
Polynucleobacter acidiphobus sp. nov., a representative of an abundant group of planktonic freshwater bacteria
}

Correspondence

Martin W. Hahn

martin.hahn@oeaw.ac.at

\author{
Martin W. Hahn, ${ }^{1}$ Elke Lang, ${ }^{2}$ Ulrike Brandt ${ }^{1}$ and Cathrin Spröer ${ }^{2}$ \\ ${ }^{1}$ Institute for Limnology, Austrian Academy of Sciences, Mondseestrasse 9, 5310 Mondsee, Austria \\ ${ }^{2}$ DSMZ - Deutsche Sammlung von Mikroorganismen und Zellkulturen GmbH, Inhoffenstraße 7b, \\ D-38124 Braunschweig, Germany
}

\begin{abstract}
The heterotrophic, aerobic, facultatively anaerobic, catalase- and oxidase-positive, non-motile strain $\mathrm{MWH}-\mathrm{PoolGreen} \mathrm{A}^{\top}$, isolated from a rock pool filled with freshwater, was characterized. The strain grew on NSY medium over a $\mathrm{NaCl}$ range of $0.0-0.3 \%(\mathrm{w} / \mathrm{v})$. Whole-cell fatty acids were dominated by $\mathrm{C}_{16: 1} \omega 7 \mathrm{c}$ (feature 3), $\mathrm{C}_{18: 1} \omega 7 \mathrm{c}$ and straight-chain $\mathrm{C}_{16: 0}$; furthermore, the components $\mathrm{C}_{12: 0}$ and $\mathrm{C}_{14: 0} 2-\mathrm{OH}$ were present. The DNA G+C content was $48.3 \mathrm{~mol} \%$. Phylogenetic analysis as well as strong similarities in phenotypic and chemotaxonomic traits indicated the affiliation with the genus Polynucleobacter. 16S rRNA gene similarity values with the three described species of the genus Polynucleobacter ranged from 96.7 to $97.8 \%$. DNA-DNA hybridization experiments did not reveal that the strain belongs to a previously described species of the genus Polynucleobacter. The strain can be discriminated from previously established species of the genus Polynucleobacter by chemotaxonomic and phenotypic traits. The bacterium possesses a free-living lifestyle and represents a group of planktonic freshwater bacteria occurring with high cell numbers in many freshwater lakes. Based on the phylogeny revealed and the chemotaxonomic and phenotypic differences from previously described species of the genus Polynucleobacter, we propose to establish the novel species Polynucleobacter acidiphobus sp. nov. with the type strain MWH-PoolGreenA3 ${ }^{\top}$ $\left(=\right.$ DSM $21994^{\top}=$ CIP $\left.110079^{\top}\right)$.
\end{abstract}

K. Heckmann and H.-J. Schmidt described the genus Polynucleobacter to accommodate bacteria thriving as obligate endosymbionts in cells of several species of freshwater ciliates belonging to the genus Euplotes (Hypotrichia), and the species Polynucleobacter necessarius for obligate endosymbionts of Euplotes aediculatus (Heckmann \& Schmidt, 1987). In 2003, strains closely related to endosymbiotic $P$. necessarius were isolated from several freshwater habitats (Hahn, 2003), and recently it was concluded that these strains represent obligately freeliving organisms, which strongly contrasts with the obligately endosymbiotic $P$. necessarius investigated previously (Vannini et al., 2007). Consequently, the description of the genus Polynucleobacter and the species $P$. necessarius was emended by adding descriptions of freeliving strains (Hahn et al., 2009) and separation of the two groups of organisms differing in lifestyle in the two subspecies $P$. necessarius subsp. necessarius (for endosymbionts

Abbreviations: FISH, fluorescent in situ hybridization; OD, optical density. The GenBank/EMBL/DDBJ accession number for the 16S rRNA gene sequence of strain MWH-PoolGreenA3 ${ }^{\top}$ is FM208180.

A supplementary figure is available with the online version of this paper. of E. aediculatus and Euplotes harpa) and P. necessarius subsp. asymbioticus (for obligately free-living strains) (Hahn et al., 2009). Other cultivated Polynucleobacter strains (Hahn, 2003; Wu \& Hahn, 2006a) were more distantly related to $P$. necessarius; therefore, strains and environmental 16S rRNA gene sequences affiliated with the monophyletic Polynucleobacter lineage were sorted in operational taxonomic units called subclusters A (PnecA), B1 (PnecB1), B2 (PnecB2), C (PnecC) and D (PnecD) (Hahn, 2003; Wu \& Hahn, 2006a). All members of PnecC and PnecD were preliminarily assigned to the species P. necessarius (Hahn et al., 2009) and Polynucleobacter cosmopolitanus (Hahn et al., 2010), respectively, and a single isolate affiliated with the phylogenetically diverse subcluster PnecA was described as Polynucleobacter rarus (Hahn et al., 2011). While many strains affiliated with subclusters PnecC and PnecD could be cultivated (Hahn, 2003; Watanabe et al., 2009), only a single strain affiliated with subcluster PnecB2 that is suitable for taxonomic characterization could be obtained so far. In this paper, we characterize this isolate, strain $\mathrm{MWH}-\mathrm{PoolGreenA} 3^{\mathrm{T}}$, and propose to establish for this strain the species Polynucleobacter acidiphobus sp. nov. 


\section{Isolation and characterization}

Strain MWH-PoolGreenA3 ${ }^{\mathrm{T}}$ was isolated from a rock pool located in a streambed of a mountain brook in Corsica, France (geographical coordinates, $42^{\circ} 10^{\prime} 21.05^{\prime \prime} \mathrm{N} 8^{\circ} 53^{\prime}$ $54.54^{\prime \prime}$ E). This rock pool represented a depression in the bedrock formed by the brook. At the time of sampling, the rock pool was isolated from the running water in the brook; however, brittle branches representing remains from a previous high-water event laying around the rock pool indicated that the pool was in contact with the brook at such an event. The brook receives water from the upstream-located Lake Creno. It is possible that the population represented by strain MWH-PoolGreenA $3^{\mathrm{T}}$ originates from this lake. The rock pool had a surface area of a few square metres and a depth of $20-30 \mathrm{~cm}$. A heavy algal bloom resulted in a green water colour and made it impossible to see the bottom of the rock pool. The water temperature was $32{ }^{\circ} \mathrm{C}$ and the conductivity was $65 \mu \mathrm{S} \mathrm{cm}{ }^{-1}$.

Strain MWH-PoolGreenA $3^{\mathrm{T}}$ was isolated and cultivated by using the filtration acclimatization method and NSY medium (Hahn et al., 2004). The strain can be maintained on NSY or R2A (Remel) medium with concentrations of $3 \mathrm{~g} \mathrm{l}^{-1}$; however, similar to all previously investigated Polynucleobacter strains, the biomass yield on these media was much lower than that observed for other members of the family Burkholderiaceae. Growth at different temperatures and growth under anoxic conditions in an anaerobic chamber were examined on NSY agar or on NSY medium supplemented with nitrate $(0.8 \mathrm{mM}) . \mathrm{NaCl}$ tolerance was determined using NSY agar supplemented with different $\mathrm{NaCl}$ concentrations $(0,0.1,0.2,0.3,0.4,0.5,0.6,0.7,1.0$, $1.25,1.5,1.75$ and $2.0 \%, \mathrm{w} / \mathrm{v})$. The temperature range supporting growth was tested on standard NSY agar plates exposed to different temperatures $(5,15,20,25,30$ and $35{ }^{\circ} \mathrm{C}$ ). Utilization of various substrates was investigated in the same way as for previously described species of the genus Polynucleobacter (Hahn et al., 2009; Hahn et al., 2010, Hahn et al., 2011). Briefly, growth enabled by utilization of a specific substrate was determined by comparison of optical density (OD) established in liquid onetenth-strength NSY medium $\left(0.3 \mathrm{~g} \mathrm{l}^{-1}\right)$ with and without $0.5 \mathrm{~g}$ test substance $\mathrm{l}^{-1}$. OD differences of $<10 \%$, of 10 $50 \%$ and of $>50 \%$ of the OD established in the medium without test substance were scored after 10 days of growth as no utilization (-), weak utilization (w) and good utilization $(+)$, respectively. Assimilation of urea and thiosulfate was tested in mineral medium IBM (Hahn et al., 2004) lacking nitrogen or sulphur sources, respectively, supplemented with acetate $\left(0.5 \mathrm{~g} \mathrm{l}^{-1}\right)$ as sole carbon and energy source and urea $\left(60 \mathrm{mg} \mathrm{l}^{-1}\right)$ or thiosulfate $(67 \mathrm{mg}$ $\left.1^{-1}\right)$, respectively.

Sequencing and phylogenetic analyses of 16S rRNA genes were performed as described previously (Hahn, 2003; Hahn et al., 2005). Sequence similarity values were determined by using the software EzTaxon (Chun et al.,
2007). Neighbour-joining trees were calculated by using the software MEGA4 (Tamura et al., 2007). The G+C content of DNA was determined as described by Tóth et al. (2008). Fatty acid methyl esters (FAMEs) were obtained as described by Kämpfer \& Kroppenstedt (1996) and separated by a gas chromatograph (model 6890, Hewlett Packard). Peaks were automatically computed using the Microbial Identification standard software package (Sasser, 1990).

The results of the phenotypic and chemotaxonomic characterization of strain MWH-PoolGreenA $3^{\mathrm{T}}$ are presented in Tables 1 and 2. The strain differed from strains of $P$. necessarius subsp. asymbioticus, $P$. rarus and $P$. cosmopolitanus in its inability to utilize fumarate and galacturonic acid (Table 3). The G $+\mathrm{C}$ content of the DNA of strain MWH-PoolGreenA3 ${ }^{\mathrm{T}}$ was $48.3 \mathrm{~mol} \%$, which is substantially higher than those of $P$. necessarius strains (44$46 \mathrm{~mol} \%)$, the P. cosmopolitanus type strain (44.9 mol\%) and the $P$. rarus type strain $(40.3 \mathrm{~mol} \%)$. Whole-cell fatty acids of strain $\mathrm{MWH}-\mathrm{PoolGreenA} 3^{\mathrm{T}}$ were dominated by the unsaturated components $\mathrm{C}_{16: 1} \omega 7 c$ (feature 3 ) and $\mathrm{C}_{18: 1} \omega 7 c$, and straight-chain $\mathrm{C}_{16: 0}$. As in $P$. necessarius subsp. asymbioticus and in $P$. rarus, considerable amounts of $\mathrm{C}_{12: 0}$ were detected which are lacking in $P$. cosmopolitanus (Table 2). Characteristic for MWH-PoolGreenA $3^{\mathrm{T}}$ in comparison to the other species of the genus Polynucleobacter were the absence of 11-methyl $\mathrm{C}_{18: 1} \omega 7 \mathrm{c}$ and the presence of $\mathrm{C}_{17: 0}$ cyclo and $\mathrm{C}_{14: 0} 2-\mathrm{OH}$. The latter two components were not found in the other species of the genus Polynucleobacter but $\mathrm{C}_{14: 0} 2-\mathrm{OH}$ was detected in several species of the related genus Cupriavidus (Fig. 1), namely $C$. campinensis, $C$. necator (earlier known as Ralstonia eutropha), C. oxalaticus (Goris et al., 2001), C. respiraculi and C. pampae (Cuadrado et al., 2010). Since every species of the genus Polynucleobacter contains a particular hydroxylated fatty acid, so far the content of hydroxylated fatty acids has turned out to be an effective measure to delineate the different species from each other.

At least some in situ grown cells of strain MWHPoolGreenA $3^{\mathrm{T}}$ can pass through membrane filters with pore sizes of $0.2 \mu \mathrm{m}$. This trait is shared with several strains affiliated with $P$. necessarius subsp. asymbioticus and $P$. cosmopolitanus, as well as with strains affiliated with other taxa (Hahn, 2004).

\section{Phylogeny}

The phylogenetic analysis of the almost complete $16 \mathrm{~S}$ rRNA gene sequence of strain MWH-PoolGreenA3 ${ }^{\mathrm{T}}$ demonstrated clustering within the genus Polynucleobacter, and indicated a close relationship with the three previously described species of this genus (Fig. 1). A more detailed phylogenetic analysis including the $16 \mathrm{~S}$ rRNA gene and 16S-23S ITS sequences of strain MWH-PoolGreenA $3^{\mathrm{T}}$ was published previously (Hahn et al., 2010). A further phylogenetic analysis (Supplementary Fig. S1, available in IJSEM Online) including environmental sequences revealed 
Table 1. Traits characterizing strain MWH-PoolGreenA ${ }^{\top}$ and strains of the previously described taxa $P$. necessarius subsp. asymbioticus, $P$. cosmopolitanus and $P$. rarus

Taxa: 1, P. acidiphobus sp. nov. MWH-PoolGreenA3 ${ }^{\mathrm{T}} ; 2$, P. necessarius subsp. asymbioticus ( $n=4$; data from Hahn et al., 2009); 3, P. cosmopolitanus ( $n=5$; Hahn et al., 2010); 4, P. rarus MT-CBb6A5 ${ }^{\mathrm{T}}$ (Hahn et al., 2011). Note that sufficient phenotypic and chemotaxonomic characterizations are lacking for the obligately endosymbiotic strains of the subspecies $P$. necessarius subsp. necessarius. All taxa are non-motile, positive for catalase and oxidase activities, grow anaerobically on NSY medium $+0.8 \mathrm{mM}$ nitrate, assimilate pyruvic acid and do not assimilate L-serine. -, Negative; + , positive; $\mathrm{w}$, weakly positive; + /-, some strains positive and some strains negative; $+/ \mathrm{W}$, some strains positive and some strains weakly positive; w/-, some strains weakly positive and some strains negative.

\begin{tabular}{|c|c|c|c|c|}
\hline Characteristic & 1 & 2 & 3 & 4 \\
\hline Cell morphology & Short curved rods & Straight or curved rods & Curved rods & Straight rods \\
\hline Nucleoids visible (DAPI) & Rarely & Rarely & Rarely & Frequently \\
\hline Cell length $(\mu \mathrm{m})$ & $0.5-1.4$ & $0.5-2.9$ & $0.4-1.4$ & $0.8-1.8$ \\
\hline Cell width $(\mu \mathrm{m})$ & $0.4-0.5$ & $0.3-0.5$ & $0.3-0.5$ & $0.6-0.8$ \\
\hline Growth at $5{ }^{\circ} \mathrm{C}$ & - & + & $+1-$ & - \\
\hline Growth at $35{ }^{\circ} \mathrm{C}$ & + & $+1-$ & + & - \\
\hline $\mathrm{NaCl}$ tolerance $(\%, \mathrm{w} / \mathrm{v})^{*}$ & 0.3 & $0.3-0.5$ & $0.3-0.5$ & $0.3(\mathrm{w})$ \\
\hline Anaerobic growth on NSY medium & + & $+1-$ & $+1-$ & - \\
\hline Growth in mineral medium with acetic acid and B12 & $\mathrm{w}$ & $\mathrm{w} /-$ & $\mathrm{w} /-$ & $\mathrm{w}$ \\
\hline \multicolumn{5}{|l|}{ Assimilation of: } \\
\hline Urea & - & $+1-$ & $+1-$ & - \\
\hline Thiosulfate & - & $+1-$ & $+1-$ & - \\
\hline Formic acid & - & $\mathrm{w} /-$ & - & - \\
\hline Glyoxylic acid & - & $\mathrm{w} /-$ & $\mathrm{w} /-$ & + \\
\hline Glycolic acid & - & - & - & $\mathrm{w}$ \\
\hline Acetic acid & w & + & + & + \\
\hline Oxalic acid & - & - & - & $\mathrm{w}$ \\
\hline Propionic acid & - & $+1-$ & $+/ \mathrm{w}$ & - \\
\hline Malonic acid & $\mathrm{w}$ & $+1-$ & $+1-$ & - \\
\hline Oxaloacetic acid & + & $+1-$ & + & - \\
\hline Malic acid & $\mathrm{w}$ & $+/ \mathrm{w}$ & + & + \\
\hline Succinic acid & $\mathrm{w}$ & + & + & + \\
\hline Fumaric acid & - & $+/ \mathrm{w}$ & + & + \\
\hline Levulinic acid & - & $\mathrm{w} /-$ & $\mathrm{w} /-$ & + \\
\hline Citric acid & - & - & $+1-$ & - \\
\hline D-Mannose & - & $\mathrm{w} /-$ & $\mathrm{w} /-$ & $\mathrm{w}$ \\
\hline D-Glucose & $\mathrm{w}$ & $\mathrm{w} /-$ & $\mathrm{w} /-$ & - \\
\hline D-Galacturonic acid & - & w & $+/ \mathrm{w}$ & + \\
\hline D-Galactose & - & $\mathrm{w} /-$ & $\mathrm{w}$ & - \\
\hline D-Lyxose & - & $\mathrm{w} /-$ & - & $\mathrm{w}$ \\
\hline D-Fructose & - & $\mathrm{w} /-$ & - & $\mathrm{w}$ \\
\hline D-Fucose & - & $\mathrm{w} /-$ & - & $\mathrm{W}$ \\
\hline D-Sorbitol & - & $\mathrm{w} /-$ & - & - \\
\hline L-Glutamate & - & $+1-$ & $\mathrm{w} /-$ & - \\
\hline L-Aspartate & - & $+1-$ & - & - \\
\hline L-Cysteine & + & $+/ \mathrm{w}$ & + & $\mathrm{w}$ \\
\hline L-Alanine & - & $\mathrm{w} /-$ & $+/ \mathrm{w}$ & - \\
\hline L-Asparagine & - & $\mathrm{w} /-$ & - & - \\
\hline Betaine & - & $\mathrm{w} /-$ & - & - \\
\hline DNA G $+\mathrm{C}$ content $(\mathrm{mol} \%)$ & 48.3 & $44-46$ & 44.9 & 40.3 \\
\hline
\end{tabular}

${ }^{\star}$ Highest $\mathrm{NaCl}$ concentration (added to NSY medium) at which growth was observed.

the affiliation of strain MWH-PoolGreenA $3^{\mathrm{T}}$ with subcluster PnecB2 (Wu \& Hahn, 2006a). This subcluster contains numerous environmental sequences retrieved from freshwater habitats located in Europe, Asia and North and Central
America. Subcluster PnecB2 is characterized by an intracluster minimum $16 \mathrm{~S}$ rRNA gene sequence similarity of $98.4 \%$, and the minimum similarity of $16 \mathrm{~S}$ rRNA gene sequences between subclusters PnecB1 and PnecB2 is 97.8\%. 
Table 2. Whole-cell fatty acid composition of strain $\mathrm{MWH}-\mathrm{Pool}-\mathrm{Green} \mathrm{3}^{\top}$ as compared with strains of $P$. rarus, $P$. cosmopolitanus and $P$. necessarius subsp. asymbioticus

Taxa: 1, Polynucleobacter acidiphobus sp. nov. MWH-Pool-GreenA3 ${ }^{\mathrm{T}}$; 2, P. rarus MT-CBb6A5 ${ }^{\mathrm{T}}$ (data from Hahn et al., 2011); 3 , P. cosmopolitanus MWH-MoIso2 ${ }^{\mathrm{T}}$ (Hahn et al., 2010); 4, P. cosmopolitanus ( $n=5$; Hahn et al., 2010); 5, P. necessarius subsp. asymbioticus QLW-P1DMWA-1 ${ }^{\mathrm{T}}$ (Hahn et al., 2009); 6, P. necessarius ( $n=3$; Hahn et al., 2009). Values are percentages of the summed fatty acids named in the peak library of the MIDI system (listed are contents $>0.2 \%$ ). Strains were grown on R2A agar plates for $3-5$ days at $28{ }^{\circ} \mathrm{C}$.

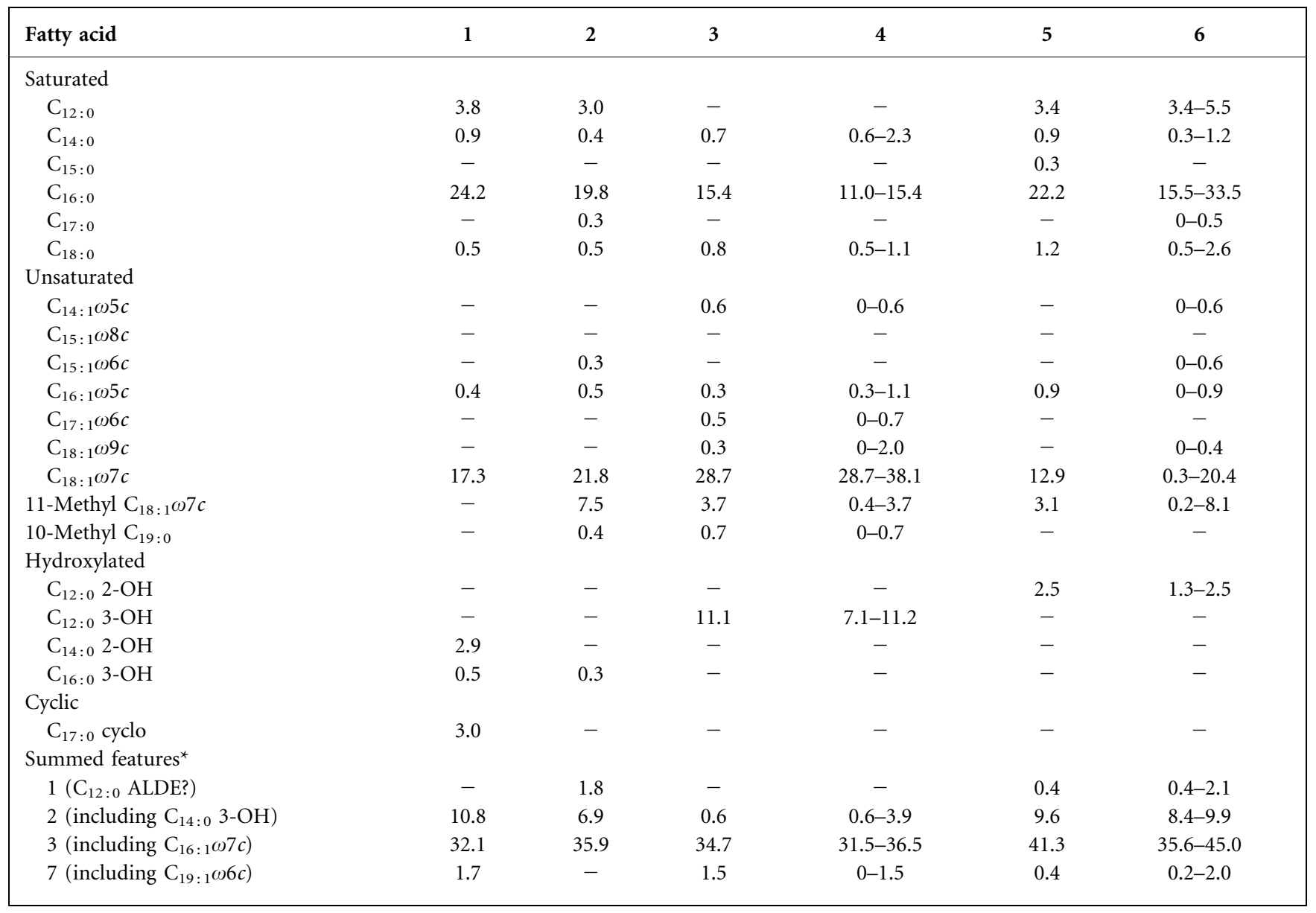

Table 3. Discriminative traits separating strain $\mathrm{MWH}-$ PoolGreen $A 3^{\top}$ from the previously described species and subspecies of the genus Polynucleobacter

Taxa: 1, Polynucleobacter acidiphobus sp. nov. MWH-PoolGreenA ${ }^{\mathrm{T}}$; 2, P. necessarius subsp. asymbioticus, $P$. cosmopolitanus and $P$. rarus (data from Hahn et al., 2009; Hahn et al., 2010; Hahn et al., 2011). Note that a phenotypic characterization of the obligately endosymbiotic $P$. necessarius subsp. necessarius is lacking. FA, fatty acids.

\begin{tabular}{|lcc|}
\hline Characteristic & $\mathbf{1}$ & $\mathbf{2}$ \\
\hline Utilization of fumarate & - & + \\
Utilization of D-galacturonic acid & - & + \\
$\mathrm{C}_{17: 0}$ cyclo (\% of summed FA) & 3.0 & Not detected \\
$\mathrm{C}_{14: 0}$ 2-OH (\% of summed FA) & 2.9 & Not detected \\
DNA G+C content (mol\%) & 48.3 & $<46$ \\
\hline
\end{tabular}

\section{Genotypic traits}

Analysis of a collection of $>300$ publicly available $16 \mathrm{~S}$ rRNA gene sequences representing cultured and uncultured strains affiliated with all four described subclusters (Hahn, 2003) revealed that members of subcluster PnecB2 are characterized by the presence of a combination of two diagnostic oligonucleotide sequences in the $16 \mathrm{~S}$ rRNA gene. Sequence 5'-AGGTAAAAGCTCACCAAGGCGAT-3' (Escherichia coli positions 258-280) is unique among Polynucleobacter PnecB2 strains; however, BLAST searches revealed that this sequence is present in some other members of the phylum Proteobacteria not affiliated with the genus Polynucleobacter. The second sequence, 5'-GGGAAGAAACASCRGCTC-3' (E. coli positions 445-463), is present in almost all species of the genus Polynucleobacter (Hahn et al., 2005) except three endosymbiotic strains, four environmental sequences and a single cultured strain. However, the combination of the two diagnostic sequences is exclusively found in the 16S rRNA sequences of strains affiliated with subcluster PnecB2. 


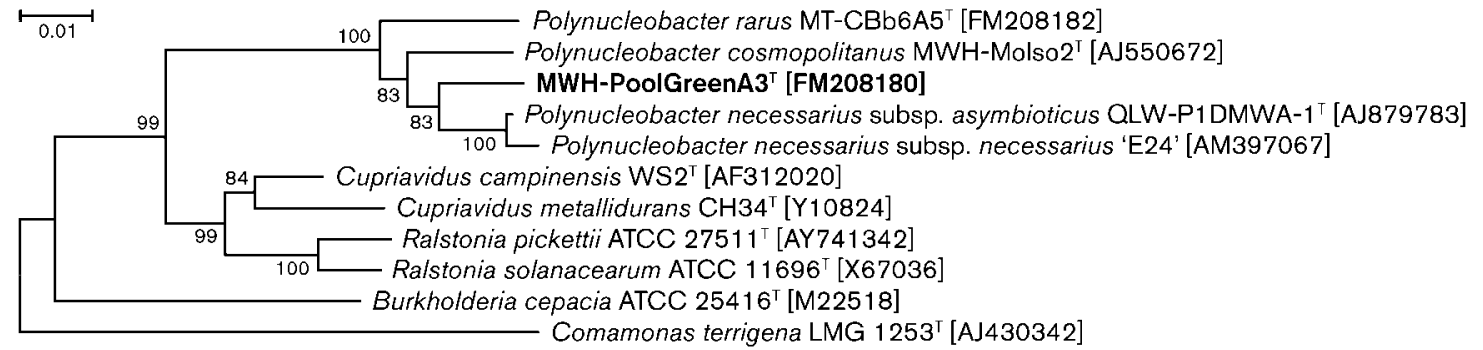

Fig. 1. Neighbour-joining tree based on almost complete $16 \mathrm{~S}$ rRNA gene sequences, reconstructing the phylogenetic position of strain MWH-PoolGreenA $3^{\top}$. Bar, 0.01 substitutions per nucleotide position. Note that previous analysis of the phylogeny of the genus Polynucleobacter based on 16S rRNA gene sequences and 16S-23S ITS sequences by the neighbour-joining and maximum-likelihood methods (Hahn et al., 2010) confirmed the phylogenetic position of strain $M W H-P o o l G r e e n A 3^{\top}$ in the Polynucleobacter clade.

\section{DNA-DNA reassociation experiments}

The sequence similarities between $16 \mathrm{~S}$ rRNA genes of strain MWH-PoolGreenA $3^{\mathrm{T}}$ and the type strain of $P$. necessarius subsp. asymbioticus, a sequence representing the endosymbiotic $P$. necessarius subsp. necessarius 'E24', the type strain of $P$. cosmopolitanus and the type strain of $P$. rarus were $97.8 \%, 97.5 \%, 97.3 \%$ and $96.7 \%$, respectively. DNA-DNA reassociation experiments were performed in order to reveal if the new strain belonged to one of the two previously described species of the genus Polynucleobacter with type strains sharing $>97 \% 16 \mathrm{~S}$ rRNA gene sequence similarity with strain MWH-PoolGreenA3 ${ }^{\mathrm{T}}$ (Stackebrandt \& Goebel, 1994). Note that experiments with DNA of a representative of $P$. necessarius subsp. necessarius could not be performed due to the lack of pure cultures (Hahn et al., 2009; Vannini et al., 2007). Duplicated reassociation experiments with the DNA of the type strain of $P$. necessarius subsp. asymbioticus resulted in DNA-DNA similarity values of $37.3 \%$ and $31.3 \%$, and duplicated experiments with the DNA of the type strain of $P$. cosmopolitanus in similarity values of $19.0 \%$ and $17.3 \%$. These results indicate that the strain does not belong to one of the previously described species of the genus Polynucleobacter when the recommendation by the ad hoc committee of a threshold value of $70 \%$ DNA-DNA similarity for delineation of prokaryotic species is considered (Wayne et al., 1987).

\section{Proposal of a novel species of the genus Polynucleobacter}

Results from the phylogenetic analysis and chemotaxonomic investigations demonstrated the affiliation of strain MWH-PoolGreenA $3^{\mathrm{T}}$ to the genus Polynucleobacter (Tables 1 and 2, Fig. 1) but also revealed pronounced differences between this strain and strains affiliated with the three previously described species of this genus. The DNA-DNA reassociation experiments performed indicated that the novel strain does not belong to the previously described species $P$. necessarius and $P$. cosmopolitanus, and the $<97 \% 16 \mathrm{~S}$ rRNA gene sequence similarity between strain MWH-PoolGreenA $3^{\mathrm{T}}$ and the type strain of $P$. rarus clearly indicated that the novel strain also does not belong to the latter species (Stackebrandt \& Goebel, 1994). Strain MWH-PoolGreenA $3^{\mathrm{T}}$ can be discriminated from previously described species of the genus Polynucleobacter by phenotypic (Table 3) and genotypic traits. Based on these findings, we propose to establish the novel species Polynucleobacter acidiphobus sp. nov. with strain $\mathrm{MWH}-$ PoolGreen $\mathrm{A} 3^{\mathrm{T}}$ as the type strain. Furthermore, we propose to preliminarily include all strains phylogenetically affiliated with subcluster PnecB2 of the Polynucleobacter lineage (Wu \& Hahn, 2006a) in this novel species. This subcluster represents a phylogenetically tight taxon separated from subcluster PnecB1 by sequence dissimilarities of 1.3-2.2\% (Supplementary Fig. S1), and members of this subcluster can be identified by genetic traits (see above). Further taxonomic investigations are necessary to clarify if subcluster PnecB2 (P. acidiphobus sp. nov.) and PnecB1 represent the same or distinct species.

\section{Ecology and biogeography of Polynucleobacter acidiphobus sp. nov.}

In contrast to the majority of free-living, non-pathogenic bacteria currently described as novel species, Polynucleobacter acidiphobus sp. nov. represents a taxon for which substantial amounts of environmental data are available. Bacteria sharing identical or almost identical 16S rRNA gene sequences with the type strain were detected in many habitats (Zwart et al., 2002; Donachie et al., 2004; Simpson et al., 2004; Wu \& Hahn, 2006a; Wu et al., 2006; Shaw et al., 2008), as well as in experimental systems (HornerDevine et al., 2003). Additional data (Wu \& Hahn, 2006a, b; Salcher et al., 2008; Alonso et al., 2009) on Polynucleobacter subcluster PnecB, which is at least partially identical with the species proposed here, were established by using a PnecB-specific fluorescent in situ hybridization (FISH) probe (Wu \& Hahn, 2006a). A survey of 65 freshwater lakes and ponds by using FISH detected members of the subcluster in $78 \%$ of the habitats investigated (Wu \& Hahn, 2006b). The relative PnecB abundance determined ranged 
from $0.4 \%$ to $13.2 \%$ with a mean of $2.6 \%$ of total bacterial numbers. The mean percentage corresponded to a mean abundance of $8 \times 10^{4} \mathrm{PnecB}$ bacteria per $\mathrm{ml}$. At two sites of a subtropical lagoon located in Uruguay, which differed in salinity, Alonso et al. (2009) observed relative abundances of PnecB bacteria of about $3 \%$ (brackish water) and $5 \%$ (freshwater) of total bacterial numbers. The highest PnecB numbers reported so far were observed in a Tibetan oligomesotrophic lake located at an altitude of $4987 \mathrm{~m}$ (Wu \& Hahn, 2006b; Wu et al., 2006). These investigations by using FISH revealed that PnecB (PnecB1 and/or PnecB2) bacteria possess a planktonic, free-living lifestyle. Importantly, all detections of PnecB bacteria by using FISH reported so far, as well as all sequence-based detections of PnecB2 bacteria reported so far, were restricted to circum-neutral and alkaline fresh and brackish waters (lakes, ponds, large rivers, estuaries). Bacteria affiliated with subclusters PnecB1 or PnecB2 were detected by cultivation independent methods in the estuaries Delaware Bay (NJ, USA) and Chesapeake Bay (MD, USA) (Shaw et al., 2008). For the latter sample, a mild salinity of 3.5 parts per thousand was reported, which is roughly equal to the maximal $\mathrm{NaCl}$ concentration tolerated by strain $\mathrm{MWH}$-PoolGreenA $3^{\mathrm{T}}$ in laboratory experiments (Table 1). As mentioned above, investigations by using FISH also detected PnecB bacteria in two parts of a subtropical coastal lagoon (Alonso et al., 2009). Interestingly, no differences in activity (i.e. uptake of labelled substrates) of the two PnecB populations dwelling in water of different salinity (freshwater and brackish water) were observed. No detections have been reported from acidic freshwaters, saline waters of high salinity (marine environments or saline inland waters) or soil systems, which supports the notion that PnecB bacteria represent typical freshwater bacteria (Zwart et al., 2002). Furthermore, indications for an endosymbiotic occurrence of PnecB bacteria are completely lacking. Wu \& Hahn (2006b) suggested that PnecB bacteria depend on autochthonous rather than on allochthonous (imported) substrate sources. This is indicated by: (i) their numerous occurrence in large lakes with long water retention times, in which only small fractions of the organic carbon are of terrestrial origin; (ii) their depth distribution, which strongly resembles typical profiles of primary production in lakes; and (iii) the numerous occurrence of PnecB bacteria in mesocosms in which primary producers have been the dominating substrate source of bacteria (Horner-Devine et al., 2003). Note that Salcher et al. (2008) did not observe a vertical distribution of PnecB bacteria in Piburger See lake similar to the abovementioned vertical distribution in Lake Mondsee.

Currently, group-specific FISH probes discriminating between PnecB1 and PnecB2 ( $P$. acidiphobus sp. nov.) are not available. Therefore, it is not known if there are groupspecific differences in ecological adaptation between these two groups. Further ecological research is required to reveal potential differences.

Strains affiliated with subcluster PnecB2 were detected in habitats located in Europe (Zwart et al., 2002; this study), Asia (Wu \& Hahn, 2006a; Wu et al., 2006), North America
(Horner-Devine et al., 2003; Simpson et al., 2004; Shaw et al., 2008), Central America (Shaw et al., 2008), on an island (Hawaii) located in the central Pacific (Donachie et al., 2004), and in East Africa (M. W. Hahn, unpublished data). The habitats of detection are located in temperate, subtropical and tropical climatic zones.

\section{Description of Polynucleobacter acidiphobus sp. nov.}

Polynucleobacter acidiphobus [a.ci.di.pho'bus. N.L. n. acidum (from L. adj. acidus sour) an acid; Gr. suff. -phobos (from Gr. n. phobos panic fear) having a horror; N.L. masc. adj. acidiphobus acid-hating, referring to the observation that this species was never detected in acidic waters].

Curved, non-motile rods, $0.5-1.4 \mu \mathrm{m}$ in length and $0.4-$ $0.5 \mu \mathrm{m}$ in width. Chemo-organotrophic, aerobic and anaerobic growth. Planktonic, free-living lifestyle. Inhabits various freshwater habitats. Can be cultivated on NSY and R2A medium. Colonies grown on NSY agar are unpigmented, circular and convex with smooth surface. Mesophilic; no growth at $5{ }^{\circ} \mathrm{C}$ but growth at $35^{\circ} \mathrm{C}$. Grows without $\mathrm{NaCl}$. Maximum $\mathrm{NaCl}$ concentration tolerated is $0.3 \%(\mathrm{w} / \mathrm{v})$. Oxidase- and catalase-positive. Utilizes acetate, pyruvate, malate, oxaloacetate, malonate, succinate, D-glucose and L-cysteine when these substrates are provided in a medium containing low amounts of NSY. Does not utilize formate, glyoxylate, glycolate, oxalate, propionate, fumarate, levulinate, citrate, D-mannose, D-galacturonic acid, D-galactose, D-lyxose, D-fructose, D-fucose, D-sorbitol, L-glutamate, L-aspartate, L-alanine, L-serine, L-asparagine or betaine. Whole-cell fatty acids are dominated by $\mathrm{C}_{16: 1} \omega 7 c$ (feature 3), $\mathrm{C}_{18: 1} \omega 7 \mathrm{c}$ and straight chain $\mathrm{C}_{16: 0}$. The components $\mathrm{C}_{12: 0}$, $\mathrm{C}_{14: 0} 2-\mathrm{OH}$ and $\mathrm{C}_{17: 0}$ cyclo are present, $\mathrm{C}_{12: 0} 2-\mathrm{OH}, \mathrm{C}_{12: 0} 3-$ $\mathrm{OH}$ and 11-methylated $\mathrm{C}_{18: 1} \omega 7 \mathrm{c}$ are absent. The DNA G+C content of the type strain is $48.3 \mathrm{~mol} \%$. Tentatively, all strains affiliated with the genus Polynucleobacter and possessing the oligonucleotide sequence 5'-AGGTAAAAGCTCACCAAGGCGAT-3' (E. coli positions 258-280) within the 16S rRNA gene shall be assigned to the proposed species.

The type strain is MWH-PoolGreenA3 ${ }^{\mathrm{T}}$ (=DSM $21994^{\mathrm{T}}$ $=\mathrm{CIP} 110079^{\mathrm{T}}$ ), isolated from a rock pool filled with freshwater located on the Mediterranean island Corsica, France.

\section{Acknowledgements}

We are grateful to P. Schumann and G. Pötter for performing the fatty acid analyses, to M. Kopitz and B. Sträubler for technical assistance, and to Jean P. Euzéby and two anonymous reviewers for etymological advice. This study was supported by the Austrian Science Fund (Project P19853 granted to M. W. H).

\section{References}

Alonso, C., Zeder, M., Piccini, C., Conde, D. \& Pernthaler, J. (2009). Ecophysiological differences of betaproteobacterial populations in 
two hydrochemically distinct compartments of a subtropical lagoon. Environ Microbiol 11, 867-876.

Chun, J., Lee, J.-H., Jung, Y., Kim, M., Kim, S., Kim, B. K. \& Lim, Y. W. (2007). EzTaxon: a web-based tool for the identification of prokaryotes based on $16 \mathrm{~S}$ ribosomal RNA gene sequences. Int J Syst Evol Microbiol 57, 2259-2261.

Cuadrado, V., Gomila, M., Merini, L., Giulietti, A. M. \& Moore, E. R. (2010). Cupriavidus pampae sp. nov., a novel herbicide-degrading bacterium isolated from agricultural soil. Int J Syst Evol Microbiol 60, 2606-2612.

Donachie, S. P., Hou, S., Lee, K. S., Riley, C. W., Pikina, A., Belisle, C., Kempe, S., Gregory, T. S., Bossuyt, A. \& other authors (2004). The Hawaiian Archipelago: a microbial diversity hotspot. Microb Ecol 48, 509-520.

Goris, J., De Vos, P., Coenye, T., Hoste, B., Janssens, D., Brim, H., Diels, L., Mergeay, M., Kersters, K. \& Vandamme, P. (2001). Classification of metal-resistant bacteria from industrial biotopes as Ralstonia campinensis sp. nov., Ralstonia metallidurans sp. nov. and Ralstonia basilensis Steinle et al. 1998 emend. Int J Syst Evol Microbiol 51, 1773-1782.

Hahn, M. W. (2003). Isolation of strains belonging to the cosmopolitan Polynucleobacter necessarius cluster from freshwater habitats located in three climatic zones. Appl Environ Microbiol 69, 5248-5254.

Hahn, M. W. (2004). Broad diversity of viable bacteria in 'sterile' $(0.2$ $\mu \mathrm{m})$ filtered water. Res Microbiol 155, 688-691.

Hahn, M. W., Stadler, P., Wu, Q. L. \& Pöckl, M. (2004). The filtrationacclimatization method for isolation of an important fraction of the not readily cultivable bacteria. J Microbiol Methods 57, 379-390.

Hahn, M. W., Pöckl, M. \& Wu, Q. L. (2005). Low intraspecific diversity in a polynucleobacter subcluster population numerically dominating bacterioplankton of a freshwater pond. Appl Environ Microbiol 71, 4539-4547.

Hahn, M. W., Lang, E., Brandt, U., Wu, Q. L. \& Scheuerl, T. (2009). Emended description of the genus Polynucleobacter and the species Polynucleobacter necessarius and proposal of two subspecies, $P$. necessarius subsp. necessarius subsp. nov. and P. necessarius subsp. asymbioticus subsp. nov. Int J Syst Evol Microbiol 59, 2002-2009.

Hahn, M. W., Lang, E., Brandt, U., Lünsdorf, H., Wu, Q. L. \& Stackebrandt, E. (2010). Polynucleobacter cosmopolitanus sp. nov., free-living planktonic bacteria inhabiting freshwater lakes and rivers. Int J Syst Evol Microbiol 60, 166-173.

Hahn, M. W., Lang, E., Tarao, M. \& Brandt, U. (2011). Polynucleobacter rarus sp. nov., a free-living planktonic bacterium isolated from an acidic lake. Int J Syst Evol Microbiol 61, 781-787.

Heckmann, K. \& Schmidt, H. J. (1987). Polynucleobacter necessarius gen. nov., sp. nov., an obligately endosymbiotic bacterium living in the cytoplasm of Euplotes. Int J Syst Bacteriol 37, 456-457.

Horner-Devine, M. C., Leibold, M. A., Smith, V. \& Bohannan, B. J. M. (2003). Bacterial diversity patterns along a gradient of primary productivity. Ecol Lett 6, 613-622.

Kämpfer, P. \& Kroppenstedt, R. M. (1996). Numerical analysis of fatty acid patterns of coryneform bacteria and related taxa. Can $J$ Microbiol 42, 989-1005.
Salcher, M. M., Pernthaler, J., Zeder, M., Psenner, R. \& Posch, T. (2008). Spatio-temporal niche separation of planktonic Betaproteobacteria in an oligo-mesotrophic lake. Environ Microbiol 10, 2074-2086.

Sasser, M. (1990). Identification of bacteria by gas chromatography of cellular fatty acids, MIDI Technical Note 101. Newark, DE: MIDI Inc.

Shaw, A. K., Halpern, A. L., Beeson, K., Tran, B., Venter, J. C. \& Martiny, J. B. (2008). It's all relative: ranking the diversity of aquatic bacterial communities. Environ Microbiol 10, 2200-2210.

Simpson, J. M., Santo Domingo, J. W. \& Reasoner, D. J. (2004). Assessment of equine fecal contamination: the search for alternative bacterial source-tracking targets. FEMS Microbiol Ecol 47, 65-75.

Stackebrandt, E. \& Goebel, B. M. (1994). Taxonomic note: a place for DNA-DNA reassociation and $16 \mathrm{~S}$ rRNA sequence analysis in the present species definition in bacteriology. Int J Syst Bacteriol 44, 846849.

Tamura, K., Dudley, J., Nei, M. \& Kumar, S. (2007). MEGA4: molecular evolutionary genetics analysis (MEGA) software version 4.0. Mol Biol Evol 24, 1596-1599.

Tóth, E. M., Kéki, Z., Homonnay, Z. G., Borsodi, A. K., Márialigeti, K. \& Schumann, P. (2008). Nocardioides daphniae sp. nov., isolated from Daphnia cucullata (Crustacea: Cladocera). Int J Syst Evol Microbiol 58, 78-83.

Vannini, C., Pöckl, M., Petroni, G., Wu, Q. L., Lang, E., Stackebrandt, E., Schrallhammer, M., Richardson, P. M. \& Hahn, M. W. (2007). Endosymbiosis in statu nascendi: close phylogenetic relationship between obligately endosymbiotic and obligately free-living Polynucleobacter strains (Betaproteobacteria). Environ Microbiol 9, 347-359.

Watanabe, K., Komatsu, N., Ishii, Y. \& Negishi, M. (2009). Effective isolation of bacterioplankton genus Polynucleobacter from freshwater environments grown on photochemically degraded dissolved organic matter. FEMS Microbiol Ecol 67, 57-68.

Wayne, L. G., Brenner, D. J., Colwell, R. R., Grimont, P. A. D., Kandler, O., Krichevsky, M. I., Moore, L. H., Moore, W. E. C., Murray, R. G. E. \& other authors (1987). Report of the ad hoc committee on reconciliation of approaches to bacterial systematics. Int J Syst Bacteriol 37, 463-464.

Wu, Q. L. \& Hahn, M. W. (2006a). Differences in structure and dynamics of Polynucleobacter communities in a temperate and a subtropical lake, revealed at three phylogenetic levels. FEMS Microbiol Ecol 57, 67-79.

Wu, Q. L. \& Hahn, M. W. (2006b). High predictability of the seasonal dynamics of a species-like Polynucleobacter population in a freshwater lake. Environ Microbiol 8, 1660-1666.

Wu, Q. L., Zwart, G., Schauer, M., Kamst-van Agterveld, M. P. \& Hahn, M. W. (2006). Bacterioplankton community composition along a salinity gradient of sixteen high-mountain lakes located on the Tibetan Plateau, China. Appl Environ Microbiol 72, 5478-5485.

Zwart, G., Crump, B. C., Kamst-van Agterveld, M. P., Hagen, F. \& Han, S.-K. (2002). Typical freshwater bacteria: an analysis of available $16 \mathrm{~S}$ rRNA gene sequences from plankton of lakes and rivers. Aquat Microb Ecol 28, 141-155. 